\title{
Milk yield, quality, and coagulation properties of 6 breeds of goats: Environmental and individual variability
}

\author{
Giuseppe M. Vacca, ${ }^{*}$ Giorgia Stocco, $\dagger^{1}$ Maria L. Dettori, ${ }^{*}$ Emanuela Pira, ${ }^{*}$ Giovanni Bittante, $\dagger$ \\ and Michele Pazzola* \\ *Department of Veterinary Medicine, University of Sassari, via Vienna 2, 07100 Sassari, Italy \\ †Department of Agronomy, Food, Natural Resources, Animals and Environment (DAFNAE), University of Padova, viale dell'Università 16, \\ 35020 Legnaro (PD), Italy
}

\section{ABSTRACT}

Goat milk and cheese production is continuously increasing and milk composition and coagulation properties (MCP) are useful tools to predict cheesemaking aptitude. The present study was planned to investigate the extension of lactodynamographic analysis up to 60 min in goat milk, to measure the farm and individual factors, and to investigate differences among 6 goat breeds. Daily milk yield (dMY) was recorded and milk samples collected from 1,272 goats reared in 35 farms. Goats were of 6 different breeds: Saanen and Camosciata delle Alpi for the Alpine type, and MurcianoGranadina, Maltese, Sarda, and Sarda Primitiva for the Mediterranean type. Milk composition (fat, protein, lactose, $\mathrm{pH}$; somatic cell score; logarithmic bacterial count) and MCP [rennet coagulation time (RCT, min), curd-firming time $\left(\mathrm{k}_{20}, \mathrm{~min}\right)$, curd firmness at 30, 45, and 60 min after rennet addition $\left(\mathrm{a}_{30}, \mathrm{a}_{45}\right.$, and $\left.\mathrm{a}_{60}, \mathrm{~mm}\right)$ ] were recorded, and daily fat and protein yield (dFPY $\mathrm{g} / \mathrm{d}$ ) was calculated as the sum of fat and protein concentration multiplied by the dMY. Data were analyzed using different statistical models to measure the effects of farm, parity stage of lactation and breed; lastly, the direct and the indirect effect of breed were quantified by comparing the variance of breed from models with or without the inclusion of linear regression of fat, protein, lactose, $\mathrm{pH}$, bacterial, somatic cell counts, and dMY. Orthogonal contrasts were performed to compare least squares means. Almost all traits exhibited high variability, with coefficients of variation between 32 (for $\mathrm{RCT}$ ) and $63 \%$ (for $\mathrm{a}_{30}$ ). The proportion of variance regarding dMY, dFPY, and milk composition due to the farm was moderate, whereas for MCP it was low, except for $\mathrm{a}_{60}$, at $69 \%$. Parity affected both yield

Received November 8, 2017.

Accepted April 5, 2018.

${ }^{1}$ Corresponding author: giorgiastocco12@gmail.com and quality traits of milk, with least squares means of $\mathrm{dMY}$ and dFPY showing an increase and RCT and curd firmness traits a decrease from the first to the last parity class. All milk quality traits, excluding fat, were affected by the stage of lactation; RCT and $\mathrm{k}_{20}$ decreased rapidly and $\mathrm{a}_{30}$ was higher from the first to the last part of lactation. Alpine breeds showed the highest dMY and dFPY but Mediterranean the best percentage of protein, fat, and lactose and a shorter $\mathrm{k}_{20}$ and a greater $\mathrm{a}_{30}$. Among the Mediterranean goats, Murciano-Granadina goats had the highest milk yield, fat, and protein contents, whereas Maltese, Sarda, and Sarda Primitiva were characterized by much more favorable technological properties in terms of $\mathrm{k}_{20}, \mathrm{a}_{30}$, and $\mathrm{a}_{45}$. In conclusion, as both the farm and individual factors highly influenced milk composition and MCP traits, improvements of these traits should be based both on modifying management and individual goat factors. As expected, several differences were attributable to the breed effect, with the best milk production for the Alpines and milk quality and coagulation for the Mediterranean goats.

Key words: caprine milk, lactodynamography, curd firmness, Alpine breeds, Mediterranean breeds

\section{INTRODUCTION}

Goat farming is a sector continuously growing, especially in low-income countries, but also in high-income ones (Morand-Fehr et al., 2004). Achieving the best performance from farmed animals is mainly gained through the empiric selection of the most productive individuals in local populations. Many of these are still limited to particular pastoral systems and can adapt to different production systems and environments considered unfavorable for other livestock species, whereas some other populations have been exported all over the world, becoming international breeds, which are suitable for intensive farming systems (Devendra and Haenlein, 2011). 
A very high percentage of goat milk is processed into typical dairy products that have a regional or local association of origin and quality (Boyazoglu and Morand-Fehr, 2001; Skeie, 2014). Moreover, goat milk is perceived to be beneficial for human health (García et al., 2014).

Goat milk and cheese production at the global level has increased by around 60\% between 1994 and 2014 (FAOSTAT, 2014). Any effort to promote scientific research in this field will be helpful for the improvement of the quality of goat milk and its products, and also for the economy of dairy goat industry. The scientific findings on goat milk products are continuously increasing, but they are mainly focused on protein polymorphisms (Moioli et al., 2007; Vacca et al., 2014) and their relationships with milk composition and coagulation properties (MCP).

Information from $\mathrm{MCP}$ has been proven to predict cheesemaking aptitude, and the most used approach to measure these traits, both at the laboratory and the industry level, is lactodynamography (Bittante et al., 2012). Traditionally, 3 single-point traits (McMahon and Brown, 1982) are recorded: rennet coagulation time (RCT, min); curd-firming rate measured as the time to a curd firmness of $20 \mathrm{~mm}\left(\mathbf{k}_{\mathbf{2 0}}, \mathbf{m i n}\right)$; and the curd firmness 30 min after enzyme addition $\left(\mathbf{a}_{\mathbf{3 0}}, \mathbf{m m}\right)$. In bovine milk, it has been reported that these renneting traits are correlated with cheese yield and the recovery of nutrients in the curd (Cecchinato and Bittante, 2016) and affect the quality of cheese (Horne and Banks, 2004). It is recognized that MCP are influenced by various environmental and genetic factors. Among the genetic factors, the MCP of ruminants are first influenced by the animal species, with the animal breed as the second most dominant factor.

However, the existing literature about MCP of goat milk is limited to a small number of single-breed analyses (Fantuz et al., 2001; Zullo et al., 2005; Inglingstad et al., 2014). A few studies use MCP to compare different breeds of goat. Comparisons rely on several breeds reared in 1 farm and represented by a small number of sampled goats per each breed (Clark and Sherbon, 2000; Thomann et al., 2008; Mestawet et al., 2013) or on bulk milk samples (Leitner et al., 2016). Data obtained in that way are not sufficiently informative to characterize a population. Another practical problem is that the sampling of small ruminants is particularly difficult, mainly when animals are reared in extensive farming systems.

In addition, a serious weakness with this topic is the difficulty in comparing results obtained in different studies, because experimental conditions, and particu- larly lactodynamographic methods, are very variable. For these reasons, we carried out a large survey in order (1) to deeply investigate the coagulative ability of goat milk and extend the lactodynamographic analysis up to $60 \mathrm{~min},(2)$ to quantify the effect variability due to farm differences, (3) to study the effects of stage of lactation and parity of goats, and (4) to compare 6 breeds of goat for their milk quality and MCP.

\section{MATERIALS AND METHODS}

\section{Farm Characteristics and Milk Sampling}

The study involved 1,272 goats reared in 35 farms located in Sardinia, an insular region of Italy. Animals were selected among those officially registered in the flock books and enrolled in the milk recording system of provincial associations of goat breeders. Farms were classified on the basis of type of management and flock size by adapting the method used for sheep by Pazzola et al. (2014a) to the actual, multisided scenario of Sardinian goat farming (Usai et al., 2006; Vacca et al., 2010, 2016).

Three management types were considered: traditional (extensive goat dairy system with free grazing of natural pastures, seasonal milk production, familyoperated), intermediate (semiextensive system, cultivated grasslands, and control of estrus and kidding season), and modern (semi-intensive system, housing in modern buildings and use of modern facilities, common use of TMR, out-of-season kidding and continuous milk production, operated by hired workers, consultancy of experts in animal feeding). Classification of management type was always performed by the same skilled operator. With regard to flock size, farms were classified as small (less than 100 producing goats), medium (100 to 200), and large (more than 200).

Farms were single $(\mathrm{n}=24)$ or multiple breeds $(\mathrm{n}=$ 11) and 6 different breeds were sampled: Saanen, (Sa), Camosciata delle Alpi (CA), Murciano-Granadina (MG), Maltese (Ma), Sarda (Sr), and Sarda Primitiva (SP). Supplemental Table S1 (https://doi.org/10 .3168/jds.2017-14111) summarizes the characteristics of sampled farms according to management, breed, flock size, and geographical area.

Goats were between the 1st and 15th parity and between 10 and 374 DIM. Individual milk samples (200 $\mathrm{mL}$ /goat) were collected during the afternoon milking (1 sampling day for each farm). Number of sampled animals per farm ranged from a minimum of 17 to a maximum of 40 . The sampled goats did not showed any clinical symptoms of disease. Samples were stored 
at $4^{\circ} \mathrm{C}$ and analyzed within $24 \mathrm{~h}$ after collection. Daily milk yield (dMY) was recorded as the total yield of morning plus evening milking.

\section{Breed Characteristics}

Saanen is an Alpine dairy specialized breed originating from Switzerland (Devendra and Haenlein, 2011) and characterized by its white coat. This international breed is very common also in Italy, mainly in the northern regions, where it is reared in intensive systems. Saanen goats sampled for the present study $(\mathrm{n}=221)$ were characterized by parity at $3.7 \pm 2.0$ (means \pm SD) and DIM at $115 \pm 49$.

The Camosciata delle Alpi is also a dairy specialized breed from Switzerland and France. Its name comes from the distinctive black and red chamoisee coat. In our study, CA goats $(\mathrm{n}=206)$ were characterized by parity and DIM very close to the Saanen breed (3.7 \pm 2.0 , and $118 \pm 47$, respectively).

Murciano-Granadina is a Mediterranean breed from Spain, characterized by a black or mahogany coat (Devendra and Haenlein, 2011). This breed is the result of the union of the herd books of the Murciana (from coastal and arid areas of southeast Spain), and the Granadina (from mountainous areas of Andalusia, Spain). Because of its good milk yield and the suitability for the intensive farming and adverse climatic conditions, it has been imported in several countries, including Italy (Oliveira et al., 2016). Parity and DIM of the MG goats sampled for the present study ( $\mathrm{n}=$ 210) were similar to those of the 2 dairy breeds of Alpine origin (parity $=3.8 \pm 2.1 ; \mathrm{DIM}=115 \pm 48$ ).

The Maltese goat is a Mediterranean local breed from the island of Sicily (Italy), where it arrived in ancient times from Malta (Criscione et al., 2016). It is a medium-sized polled goat, with black and white coat and long hanging ears, well adapted to free grazing extensive farming. Maltese goats $(\mathrm{n}=210)$ were characterized by parity at $3.9 \pm 2.0$ and DIM at $121 \pm 45$.

Sarda and Sarda Primitiva are local breeds from the island of Sardinia (Italy), classified as Mediterranean types (Pazzola et al., 2014b; Vacca et al., 2016). Both are managed in semiextensive farming systems. Sarda Primitiva has been recently recognized as the original strain of Sardinian local breed, and it is a limited size population, with about 6,000 animals recorded in the flock book (DAD-IS, 2014). Sarda goats sampled for our study $(\mathrm{n}=212)$ had parity at $3.6 \pm 1.9$ and DIM at $113 \pm 41$, whereas SP $(\mathrm{n}=213)$ was characterized by the highest value of parity $(5.2 \pm 2.4)$ and DIM (129 $\pm 43)$.

\section{Analysis of Milk Samples}

Analysis of milk composition and MCP were performed following the same methods reported in Pazzola et al. (2014a). Briefly, fat, protein, lactose, and pH were measured using a MilkoScan FT6000 milk analyzer (Foss Electric A/S, Hillerød, Denmark); daily fat and protein yield (dFPY g/d) was calculated as the sum of fat and protein concentration multiplied by the dMY; SCC was determined by a Fossomatic 5000 somatic cell counter (Foss Electric A/S) and transformed into the logarithmic $\left[\log _{2}\left(\mathrm{SCC} \times 10^{-5}\right)+3\right] \mathrm{SCS}$; and total bacterial count (TBC) was measured by a BactoScan FC150 analyzer (Foss Electric A/S) and transformed into the logarithmic bacterial count $\left[\mathbf{L B C}=\log _{10}\right.$ (total bacterial count/1,000)].

Analysis of MCP was performed using the Formagraph instrument (Foss Italia S.P.A., Padova, Italy). Rennet (Hansen Naturen Plus 215, Pacovis Amrein AG, Bern, Switzerland) was diluted in distilled water to obtain a solution at $1.2 \%$ (wt/vol), with a final value of 0.0513 international milk clotting units IMCU per milliliter of milk. The MCP recorded as RCT (min), the time interval between rennet addition and gelation; curd-firming time $\left(\mathrm{k}_{20}, \mathrm{~min}\right)$, the time between gelation and the attainment of curd firmness of $20 \mathrm{~mm}$; and curd firmness at 30, 45, and 60 min after rennet addition $\left(\mathrm{a}_{30}, \mathrm{a}_{45}\right.$, and $\mathrm{a}_{60}, \mathrm{~mm}$, respectively). For milk samples that did not coagulate within 60 min after rennet addition $(\mathrm{n}=16)$, $\mathrm{RCT}$ was considered to be missing. Curd firmness was considered missing when the result was $0\left(\mathrm{a}_{30}: \mathrm{n}=42 ; \mathrm{a}_{45}: \mathrm{n}=18 ; \mathrm{a}_{60}: \mathrm{n}=16\right)$.

\section{Statistical Analysis}

Experimental data regarding MCP were analyzed using a MIXED procedure (SAS Institute Inc., Cary, $\mathrm{NC})$, according to the model

$$
\begin{aligned}
\mathrm{y}_{\mathrm{mnopqr}}=\mu & + \text { Farm }_{\mathrm{m}}+\text { Breed }_{\mathrm{n}}+\text { Parity }_{\mathrm{o}}+\text { DIM }_{\mathrm{p}} \\
& + \text { Pendulum }_{\mathrm{q}}+\mathrm{e}_{\mathrm{mnopqr}}[\mathrm{M} 1]
\end{aligned}
$$

where $\mathrm{y}_{\text {mnopqr }}$ is the observed MCP trait $\left(\mathrm{RCT}, \mathrm{k}_{20}, \mathrm{a}_{30}\right.$, $\left.\mathrm{a}_{45}, \mathrm{a}_{60}\right) ; \mu$ is the overall intercept of the model; Farm $_{\mathrm{m}}$ is the random effect of the mth farm ( $\mathrm{m}=1$ to 35$)$; Breed $_{n}$ is the fixed effect of the nth breed $(n=$ Sa,

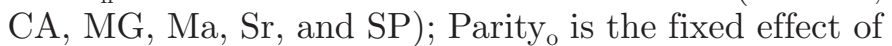
the oth parity $[\mathrm{o}=1$ to 3 ; class $1=1$ st and 2 nd (392 samples); class $2=3 \mathrm{rd}$ and 4 th (460 samples); class 3 $=\geq 5$ th (420 samples)]; DIM ${ }_{\mathrm{p}}$ is the fixed effect of the pth class of days in milk $[\mathrm{p}=1$ to 4 ; class $1=<80 \mathrm{~d}$ 
Table 1. Descriptive statistics of yield traits and of quality traits and coagulation properties of milk samples ${ }^{1}$

\begin{tabular}{|c|c|c|c|c|c|c|}
\hline Item & $\mathrm{N}$ & Mean & $\mathrm{SD}$ & $\mathrm{CV}, \%$ & P5th & P95th \\
\hline \multicolumn{7}{|l|}{ Yield traits, $\mathrm{kg} / \mathrm{d}$} \\
\hline Milk yield & 1,257 & 1.85 & 1.09 & 59 & 0.42 & 3.88 \\
\hline Fat and protein yield & 1,258 & 0.14 & 0.07 & 50 & 0.04 & 0.27 \\
\hline \multicolumn{7}{|l|}{ Quality traits of milk } \\
\hline Fat, \% & 1,258 & 4.60 & 1.44 & 31 & 2.69 & 7.31 \\
\hline Protein, \% & 1,251 & 3.61 & 0.55 & 15 & 2.84 & 4.64 \\
\hline Lactose, \% & 1,254 & 4.65 & 0.27 & 6 & 4.19 & 5.07 \\
\hline $\mathrm{pH}$ & 1,260 & 6.72 & 0.11 & 2 & 6.54 & 6.90 \\
\hline $\mathrm{SCS},{ }^{2} \mathrm{U}$ & 1,271 & 5.79 & 2.01 & 35 & 2.55 & 9.13 \\
\hline $\mathrm{LBC},{ }^{3} \mathrm{U}$ & 1,253 & 1.70 & 0.79 & 46 & 0.48 & 3.06 \\
\hline \multicolumn{7}{|c|}{ Milk coagulation properties ${ }^{4}$} \\
\hline $\mathrm{RCT}, \min$ & 1,234 & 13.2 & 4.4 & 33 & 7.30 & 22.00 \\
\hline $\mathrm{k}_{20}, \min$ & 1,183 & 4.5 & 2.4 & 53 & 2.15 & 9.30 \\
\hline $\mathrm{a}_{30}, \mathrm{~mm}$ & 1,218 & 36.0 & 12.2 & 34 & 16.00 & 55.00 \\
\hline $\mathrm{a}_{45}, \mathrm{~mm}$ & 1,248 & 36.2 & 12.8 & 35 & 14.14 & 56.56 \\
\hline $\mathrm{a}_{60}, \mathrm{~mm}$ & 1,226 & 27.8 & 17.5 & 63 & 2.36 & 55.00 \\
\hline
\end{tabular}

${ }^{1} \mathrm{P} 5$ th and P95th $=5$ th and 95th percentiles, which indicate the upper and lower 5\% limits in the 2-tailed distribution of data.

${ }^{2} \mathrm{SCS}=\log _{2}\left(\mathrm{SCC} \times 10^{-5}\right)+3$.

${ }^{3} \mathrm{LBC}=\operatorname{logarithmic} 1$ bacterial count $=\log _{10}($ total bacterial count $/ 1,000)$.

${ }^{4} \mathrm{RCT}=$ measured rennet gelation time; $\mathrm{k}_{20}=$ time interval between gelation and attainment of curd firmness of $20 \mathrm{~mm} ; \mathrm{a}_{30}, \mathrm{a}_{45}$, and $\mathrm{a}_{60}=$ curd firmness 30,45 , and $60 \mathrm{~min}$ after rennet addition, respectively.

(329 samples); class $2=81-120 \mathrm{~d}$ (350 samples); class $3=121-160 \mathrm{~d}$ (352 samples); class $4=>160 \mathrm{~d}$ (241 samples)]; Pendulum ${ }_{\mathrm{q}}$ is the random effect of the qth measuring unit of the Formagraph instrument $(\mathrm{q}=1$ to 10$)$; and $\mathrm{e}_{\mathrm{mnopqr}}$ is the random residual $\sim N\left(0, \sigma_{\mathrm{e}}^{2}\right)$, where $\sigma$ is the standard deviation.

The daily yield traits, dMY and dFPY, and chemical components (fat, protein, lactose, $\mathrm{pH}, \mathrm{SCS}$, and LBC) of milk were analyzed using an additional model [M2] derived from model [M1] without the random factor of the pendulum. A further model [M3] derived from [M1], but with breed computed as random factor, was used to obtain a correct quantification of breed variance and analyze the total effects of breed on MCP traits. Lastly, a fourth model [M4] was used to quantify the direct effect of breed (i.e., the effect of breed corrected at the same dMY and milk quality traits), by also including in [M3] the linear covariates of dMY, fat, protein, and lactose percentage, $\mathrm{pH}, \mathrm{SCS}$, and LBC. The indirect effect of breed on MCP due to breed differences in terms of MY and quality was obtained by subtracting the breed variance obtained by the model [M4] from the breed variance obtained from model [M3]. Both direct and indirect breed variance were represented as percentage of total breed variance.

Orthogonal contrasts were estimated between least squares means of traits for the breed effect: (a) Alpine (Sa and CA) versus Mediterranean breeds (MG, Ma, $\mathrm{Sr}$, and SP); (b) between the 2 Alpine breeds (Sa vs. $\mathrm{CA})$; (c) within the 4 Mediterranean, comparing the Spanish to Italian breeds (MG vs. Ma, Sr, and SP); (d) within the 3 Italian breeds, comparing the Sicil- ian to the Sardinian breeds (Ma vs. Sr and PR); and (e) comparing the 2 breeds from Sardinia (Sr vs. SP). Orthogonal contrasts were estimated also between least squares means of traits for parity effect [(a) 1st and 2nd versus $\geq 3 \mathrm{rd}$, and (b) $3 \mathrm{rd}$ and 4 th versus $\geq 5$ th] and DIM (linear, quadratic, and cubic pattern).

\section{RESULTS}

\section{Milk Quality and Renneting Properties}

Descriptive statistics of yield traits (dMY and dFPY), chemical composition, and coagulation properties of milk samples are summarized in Table 1. All traits, $\mathrm{pH}$ and lactose excluded, exhibited high variability due to the diversity of the farms and of the 6 sampled breeds. Especially for yield traits, the coefficient of variation was greater than $50 \%$, whereas the coefficient of variation for MCP was between 33\% (for RCT) and 63\% (for $\mathrm{a}_{30}$ ).

\section{Effect of Farm}

Variances of yield traits, milk quality, and MCP are shown in Figure 1. Regarding yield traits and milk composition, the proportion of variance due to the farm was moderate, whereas it was high for LBC. The other quality traits were characterized by a small incidence of this effect (from 16\% for SCS content to $44 \%$ for fat). In the case of MCP, the farm effect was low if compared with the same effect on yield traits, but was very high for $\mathrm{a}_{60}(69 \%)$. 


\section{Effects of Parity and DIM}

Parity affected both yield and quality traits of milk, except for fat, protein content, and LBC. Least squares means of classes of parity showed that dMY and dFPY increased particularly from the first and second lactations to the following ones, as expected (Table 2). Lactose and acidity of milk tended to decrease linearly across classes of parity, whereas SCS showed an opposite trend. Milk from goats belonging to the first class of parity attained a faster RCT and a greater curd firmness than goats with 3 or more parities, but with similar curd-firming time $\left(\mathrm{k}_{20}\right)$.

The variation during lactation was highly significant for all milk quality traits, excluding fat (Table 3). Protein content showed a quadratic pattern, with the lowest average values for samples collected 80 to 120 DIM (3.53\%), and then increased almost linearly until the end of lactation (3.78\%). Regarding SCS and LBC, these tended to increase linearly during lactation, passing from 5.37 and 1.59 , respectively, in the first $80 \mathrm{~d}$ to 6.36 and 1.81, respectively, in the last part of lactation.

Regarding MCP, DIM affected all the coagulative traits, except for the final part of coagulation (curd firmness at 45 and $60 \mathrm{~min}$ ). It is evident from Table 3 that RCT decreased rapidly from the first to the last part of lactation. The $\mathrm{k}_{20}$ and $\mathrm{a}_{30}$ became more favorable, with a marked reduction from the beginning to the end of lactation (linear pattern). Even if not significant, improvements were observed also for $\mathrm{a}_{45}$ and $\mathrm{a}_{60}$ toward the end of lactation.

\section{Effect of Breed}

Least squares means of breed effect and their orthogonal contrasts ( $F$-value) for all the observed traits are reported in Table 4. All least squares means are corrected for the other factors of variation included in [M1] (farms, parity, and DIM of the goats).

Comparing the averages of the 2 Alpine breeds ( $\mathrm{Sa}$ and CA) with the 4 Mediterranean breeds (MG, Ma, $\mathrm{Sr}$, and SP), it is easy to notice the high difference in dMY (46\%) and dFPY (38\%; data not shown in tables). However, Mediterranean breeds overcame Alpine breeds for the 3 major chemical components (percentage of protein, fat, and lactose) and $\mathrm{pH}$, and were characterized by a shorter $\mathrm{k}_{20}$ and a greater $\mathrm{a}_{30}$.

The 2 Alpine breeds (Sa vs. CA) did not differ from each other, with the sole exception of milk $\mathrm{pH}$, slightly lower in milk from the Sa. Within the 4 Mediterranean breeds, differences were observed for some traits. Compared with the Spanish MG, the Italian breeds

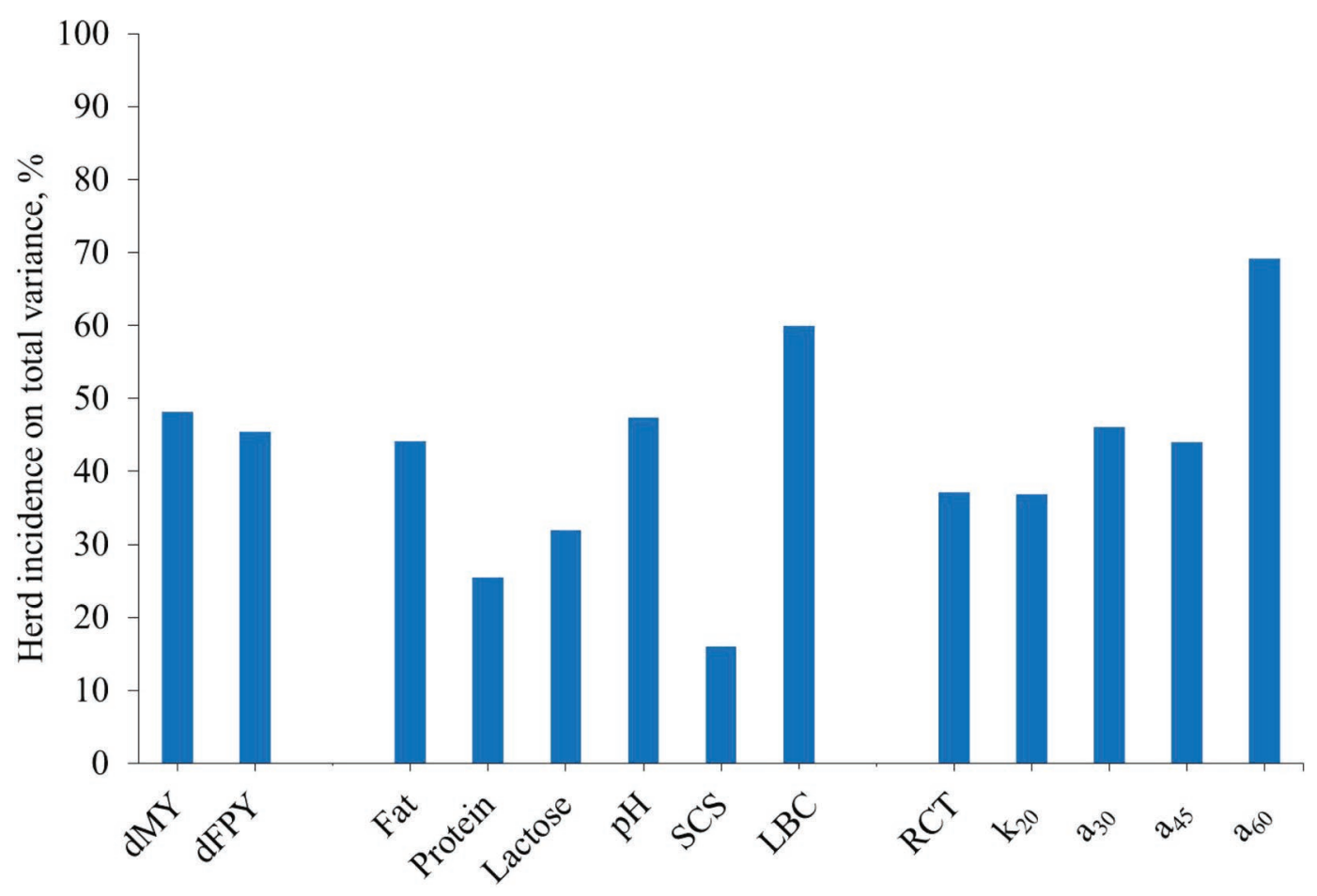

Figure 1. Farm effect on yield traits, and for quality traits and coagulation properties of milk samples. dMY $=$ daily milk yield; dFPY $=$ daily fat and protein yield; $\mathrm{LBC}=$ logarithmic bacterial count; RCT $=$ measured rennet gelation time; $\mathrm{k}_{20}=$ time interval between gelation and attainment of curd firmness of $20 \mathrm{~mm} ; \mathrm{a}_{30}, \mathrm{a}_{45}$, and $\mathrm{a}_{60}=$ curd firmness 30,45 , and $60 \mathrm{~min}$ after rennet addition. Color version available online. 
Table 2. Least squares means of parity effect and their orthogonal contrasts ( $F$-value) of yield traits, chemical composition, and coagulation properties of milk samples

\begin{tabular}{|c|c|c|c|c|c|}
\hline \multirow[b]{2}{*}{ Item } & \multicolumn{3}{|c|}{ Parity } & \multicolumn{2}{|c|}{ Parity contrast ( $F$-value) } \\
\hline & 1st and 2 nd & 3rd and 4 th & $\geq 5$ th & 1st and 2 nd vs. $\geq 3$ rd & $3 \mathrm{rd}$ and 4 th vs. $\geq 5$ th \\
\hline Milk yield & 1.76 & 1.95 & 1.88 & $12.9^{* * *}$ & 2.0 \\
\hline Fat and protein yield & 0.14 & 0.15 & 0.14 & $12.8^{* * *}$ & 1.8 \\
\hline \multicolumn{6}{|l|}{ Quality traits of milk } \\
\hline Fat, \% & 4.63 & 4.61 & 4.54 & 0.7 & 0.2 \\
\hline $\mathrm{pH}$ & 6.73 & 6.72 & 6.71 & $8.0^{*}$ & 1.4 \\
\hline $\mathrm{SCS},{ }^{1} \mathrm{U}$ & 5.13 & 5.78 & 6.52 & $61.7^{* * *}$ & $31.7^{* * *}$ \\
\hline $\mathrm{LBC}^{2} \mathrm{U}$ & 1.71 & 1.69 & 1.70 & 0.1 & 0.1 \\
\hline \multicolumn{6}{|c|}{ Milk coagulation properties ${ }^{3}$} \\
\hline $\mathrm{RCT}, \min$ & 12.6 & 13.2 & 13.3 & $6.3^{*}$ & 0.1 \\
\hline $\mathrm{k}_{20}, \min$ & 4.3 & 4.5 & 4.6 & 2.6 & 0.7 \\
\hline $\mathrm{a}_{30}, \mathrm{~mm}$ & 37.6 & 35.9 & 34.9 & $11.9^{* * *}$ & 2.7 \\
\hline
\end{tabular}

${ }^{1} \mathrm{SCS}=\log _{2}\left(\mathrm{SCC} \times 10^{-5}\right)+3$.

${ }^{2} \mathrm{LBC}=\operatorname{logarithmic}$ bacterial count $=\log _{10}$ (total bacterial count $\left./ 1,000\right)$.

${ }^{3} \mathrm{RCT}=$ measured rennet gelation time; $\mathrm{k}_{20}=$ time interval between gelation and attainment of curd firmness of $20 \mathrm{~mm} ; \mathrm{a}_{30}, \mathrm{a}_{45}$, and $\mathrm{a}_{60}=\mathrm{curd}$ firmness 30,45 , and 60 min after rennet addition.

${ }^{*} P<0.05$; ${ }^{*} P<0.01$; ${ }^{* * *} P<0.001$.

confirmed on average their smaller productive potential $(\mathrm{dMY}=-44 \%$; dFPY $=-41 \%)$, but also their superiority in terms of milk fat $(13 \%)$ and protein $(10 \%)$ contents (data not shown). Milk from the 3 Italian breeds (Mal, Sr, and SP) was characterized, on average, by much more favorable technological properties in terms of $\mathrm{k}_{20}, \mathrm{a}_{30}$, and $\mathrm{a}_{45}$ (Table 4 ).

Within the 3 Italian breeds, when compared with $\mathrm{Ma}, \mathrm{Sr}$, and SP, goats showed lower productive potential in terms of yield traits $(\mathrm{kg} / \mathrm{d})$, compensated by a

Table 3. Least squares means of DIM effect and their orthogonal contrasts ( $F$-value) of yield traits and quality traits and coagulation properties of milk samples

\begin{tabular}{|c|c|c|c|c|c|c|c|}
\hline Item & \multicolumn{4}{|c|}{ DIM } & \multicolumn{3}{|c|}{ DIM contrast ( $F$-value) } \\
\hline \multicolumn{8}{|l|}{ Yield traits, kg/d } \\
\hline Milk yield & 1.92 & 1.88 & 1.83 & 1.82 & 2.0 & 0.2 & 0.1 \\
\hline Fat and protein yield & 0.15 & 0.14 & 0.14 & 0.14 & 0.2 & 0.5 & 0.0 \\
\hline \multicolumn{8}{|l|}{ Quality traits of milk } \\
\hline Fat, \% & 4.61 & 4.61 & 4.56 & 4.58 & 0.2 & 0.0 & 0.2 \\
\hline $\mathrm{pH}$ & 6.75 & 6.72 & 6.71 & 6.71 & $20.2^{* * *}$ & $4.1^{*}$ & 0.2 \\
\hline $\mathrm{SCS},{ }^{1} \mathrm{U}$ & 5.37 & 5.66 & 5.86 & 6.36 & $21.3^{* * *}$ & 0.6 & 0.6 \\
\hline $\mathrm{LBC},{ }^{2} \mathrm{U}$ & 1.59 & 1.68 & 1.72 & 1.81 & $11.0^{* *}$ & 0.0 & 0.3 \\
\hline \multicolumn{8}{|c|}{ Milk coagulation properties ${ }^{3}$} \\
\hline $\mathrm{RCT}, \min$ & 14.0 & 12.7 & 12.8 & 12.6 & $7.6^{* *}$ & 2.7 & 2.0 \\
\hline $\mathrm{k}_{20}, \min$ & 4.9 & 4.4 & 4.4 & 4.2 & $7.9^{* *}$ & 1.8 & 1.9 \\
\hline $\mathrm{a}_{30}, \mathrm{~mm}$ & 33.6 & 36.2 & 36.6 & 38.1 & $17.2^{* * *}$ & 0.9 & 1.4 \\
\hline
\end{tabular}

${ }^{1} \mathrm{SCS}=\log _{2}\left(\mathrm{SCC} \times 10^{-5}\right)+3$.

${ }^{2} \mathrm{LBC}=\operatorname{logarithmic}$ bacterial count $=\log _{10}$ (total bacterial count $\left./ 1,000\right)$.

${ }^{3} \mathrm{RCT}=$ measured rennet gelation time; $\mathrm{k}_{20}=$ time interval between gelation and attainment of curd firmness of $20 \mathrm{~mm} ; \mathrm{a}_{30}, \mathrm{a}_{45}, \mathrm{and}_{60}=\mathrm{curd}$ firmness 30, 45, and 60 min after rennet addition.

${ }^{*} P<0.05 ; * *<0.01 ; * * *<0.001$. 
VACCAETAL.

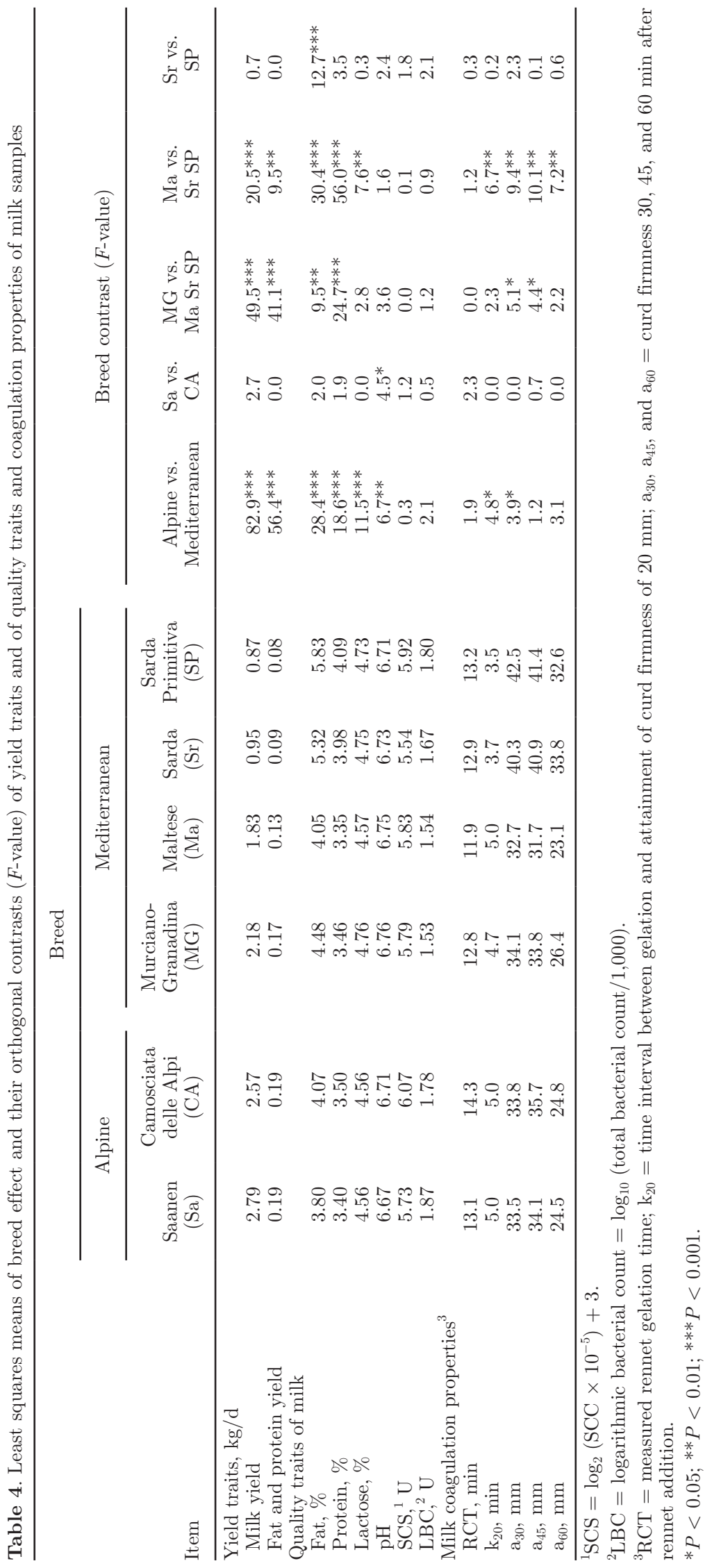


greater percentage of fat and protein in milk (38 and $20 \%$, respectively, data not shown), and especially by much more favorable technological properties of milk produced, in terms of all the 3 curd firmness traits. As regards the autochthonous Sardinian breeds, it is possible to notice that the difference in yield traits did not attain the statistical difference; however, milk from SP goats was characterized by higher fat content $(10 \%$, data not shown)

\section{DISCUSSION}

\section{Coagulative Ability of Goat Milk}

The lactodynamograph is the most common instrument used to measure MCP; it has been designed to evaluate bovine milk, but it is also used to study the milk of other species. However, as reported by Bittante et al. (2012), the 30-min lactodynamograph test could distort the information provided by MCP. In addition, the information gained within 30 min of analysis could bias also the comparison among species, breeds, or dairy systems, characterized by different incidence of noncoagulating (NC) samples and by different coagulative ability.

An indirect comparison of goats with other species could be done summarizing the MCP obtained by our research groups in other surveys on sheep, buffalo, and cow milk using the same procedure and experimental conditions. Coagulation time of caprine milk is intermediate between those of ovine (Bittante et al., 2014; Pazzola et al., 2014a) and bovine species (CipolatGotet et al., 2012; Stocco et al., 2017) and not much different from buffalo (Cecchinato et al., 2012). For $\mathrm{k}_{20}$ and $\mathrm{a}_{30}$ traits, goat milk was similar to cow and buffalo, whereas a clear difference could be observed in the pattern of curd firmness after 30 min from rennet addition. Indeed, curd firmness of bovine milk shows a slow increase until $60 \mathrm{~min}$, confirming the need of longer times for reaching maximum firmness of curd (Cipolat-Gotet et al., 2012; Stocco et al., 2017). Ovine milk (Bittante et al., 2014; Pazzola et al., 2014a) shows a slow decrease of curd firmness after 30 min, confirming that maximum curd firmness is reached by the large majority of milk sample before 30 min after enzyme addition (Vacca et al., 2015). Goat milk reached the maximum curd firmness, on average, between 30 and 45 min after rennet addition, but thereafter showed a rapid decrease of curd firmness that can be interpreted as a rapid increase of curd syneresis (Bittante et al., 2013). The entity of syneresis is different in each species (Calvo and Balcones, 2000), and it is also highly affected by breed within species (Stocco et al., 2017).
As far as we are aware, very few studies prolonged the observation of MCP of goat milk over $30 \mathrm{~min}$. Those studies used optical instruments (Leitner et al., 2016), and results have been proven to be mismatched with those provided by lactodynamographs (Cipolat-Gotet et al., 2012) or rheometers (Clark and Sherbon, 2000; Thomann et al., 2008), whose records require further evaluation or, at least, proper comparison with lactodynamography data. In goat species, we are aware no study that has prolonged the analysis until $60 \mathrm{~min}$ using the common approach (lactodynamograph), obtaining further information about the firmness of the curd at 45 and 60 min. Hence, prolonging the analysis to $60 \mathrm{~min}$ allowed us to speculate about the renneting aptitude of goat milk and syneresis of the curd. In the present study, the samples that coagulated within 30 min were $97 \%$, the NC samples were $1 \%$ (samples without any MCP measures), and the remaining portion $(2 \%)$ comprised samples that coagulated between 30 and $60 \mathrm{~min}$ of analysis (late-coagulating samples). Observing the information provided by $\mathrm{a}_{30}, \mathrm{a}_{45}$, and $\mathrm{a}_{60}$, it is also possible to affirm that, on average, a rapid increase in the curd firming process and the presence of variable degrees of syneresis occurred, meaning that curd firmness at $30 \mathrm{~min}$ or later is often measured in the descending part of the lactodynamographic curve.

\section{Variability Among Farms}

The present study showed that the effect of farm represented a variable proportion (from $16 \%$ for SCS to $69 \%$ for $\mathrm{a}_{60}$ ) of total variability according to the trait considered (Figure 1). Few research papers have considered the effect of farm on goat milk quality traits and coagulation properties (Zullo et al., 2005; Pazzola et al., 2011, 2014b), but in those studies authors treated farm as a fixed factor in their models; therefore, they could not estimate the corresponding variance component to express that as a proportion of total variance. However, our results can be compared with those proposed by some authors in bovine milk, even if it is important to take into account that goat farming systems are much more diversified from each other than bovine systems. Especially for MCP, the incidence of farm variability was higher compared with the results found in different bovine dairy breeds (Tyrisevä et al., 2003; Ikonen et al., 2004; Stocco et al., 2017). Given that farm effect is made up numerous diverse aspects, such as the type of management (traditional, intermediate, modern), altitude (plains, hills, mountains), and flock size (small, medium, large), the percentage of variability could be considered moderate to intermediate for the majority of the traits studied, with the exception of milk LBC and 
curd firmness at $60 \mathrm{~min}$ of analysis. This means that milk composition and MCP were affected principally by individual residual animal factors of variation and less by environmental or management factors.

\section{Effect of Parity and Lactation Stage}

Table 2 shows several differences across classes of parities of dMY, dFPY, lactose, and SCS content. As expected, daily milk yield and SCS increased with parity order. On the contrary, Zeng and Escobar (1995) found no statistical differences across classes of parities with regard to milk components, but dMY was smaller in the first class. Lôbo et al. (2017) found a significant decrease for all the milk components analyzed from the 1st to the 7th parity.

Regarding MCP, parity has often been considered in statistical models in studies of bovine species (Stocco et al., 2017), with a significant decrease of curd firmness across parity levels, in accordance with our results in goat milk. No difference was observed for RCT and $k_{20}$; hence, goats showed a decrease of curd firmness in the 2 last classes of parity (i.e., from the third kidding).

Regarding the effects of lactation stage, Table 3 clearly showed that the effect of DIM was important for coagulation, especially for curd firming time and curd firmness at $30 \mathrm{~min}$. In contrast with the literature for bovine milk (Ikonen et al., 2004; Cipolat-Gotet et al., 2012), and in agreement with the results for ovine milk (Pazzola et al., 2014a), the present study showed that milk produced at the end of lactation was characterized by better RCT (about 2 min shorter) and $\mathrm{k}_{20}$ (about 1 min shorter) and greater $\mathrm{a}_{30}$ (about $5 \mathrm{~mm}$ ).

\section{Effect of Breed}

As no previous research paper studying MCP obtained data from a large number of sampled animals of several goat breeds, direct comparisons of the data with earlier reports are not feasible. However, some data are available for goat milk quality and coagulative parameters.

Alpine versus Mediterranean breeds showed large differences, that confirmed the high productive potential of the former and the high-quality milk value of the latter. They also showed differences in terms of technological properties, with the goal of shorter $k_{20}$ and greater $\mathrm{a}_{30}$. It is worth noting that curd firmness is the most important technological parameter for dairy plants, and its relevance at research level is confirmed in cattle by Cecchinato and Bittante (2016).

Between the 2 Alpine breeds, no differences were observed for all the traits studied ( $\mathrm{pH}$ excluded), confirming the results of Clark and Sherbon (2000). In contrast, Ambrosoli et al. (1988) reported that milk from Camosciata delle Alpi goats is characterized by better coagulation properties (shorter RCT, greater curd firmness) than milk from Saanen.

Large differences were observed among the Mediterranean dairy breeds. The MG, compared with the 3 Italian breeds, was characterized by higher milk yield, but lower fat and protein contents. The 3 Italian breeds also showed better renneting properties compared with MG breed, producing milk with shorter $\mathrm{k}_{20}$ and greater curd firmness.

The 2 local breeds from Sardinia are of environmental and sociocultural importance, as they are related to traditions and typical food products. As shown in previous studies (Pazzola et al., 2014b), Sr goats are characterized by a short RCT and very high values of curd firmness. The differences between $\mathrm{Sr}$ and SP did not attain statistical significance except for fat content.

As this is the first study focusing on MCP of many goat milk samples of different breeds, we wanted to evaluate the direct effects of breed on MCP independently from its indirect effects on MCP due to the differences among breeds in milk yield and composition. Hence, we investigated this by modifying the original [M1] statistical model by treating breed as a random factor [M3] and including dMY, fat, protein, lactose, $\mathrm{pH}$, SCS, and LBC as general covariates [M4]. The results (not shown in tables) showed that, in general, dMY had a small effect on MCP traits; a favorable effect was exerted by fat (especially on RCT), protein, and lactose (on all traits) contents, whereas the increase of $\mathrm{pH}, \mathrm{SCS}$ and LBC were unfavorably related to lactodynamographic traits.

It can be seen from Figure 2 that the proportions of direct and indirect effects of goats breed are very different for RCT, $\mathrm{k}_{20}$, and curd firmness traits $\left(\mathrm{a}_{30}, \mathrm{a}_{45}\right.$, and $\left.\mathrm{a}_{60}\right)$. Indeed, in the case of RCT, the differences among the 6 breeds were even greater ( $82 \%$ of breed variance) after correction for milk yield and composition [M4] than before [M3].

On the contrary, in the cases of $\mathrm{k}_{20}, \mathrm{a}_{30}$, and $\mathrm{a}_{45}$, about $90 \%$ of total breed effect was shown to be a consequence of the differences among breeds in terms of milk yield and composition. After correcting the MCP for milk yield and composition, the breed effect was very low (and nonsignificant). In cattle species, phenotypic and genetic correlations between milk quality and MCP are often high (Bittante et al., 2012), but no information is available in the literature regarding goats.

Different from $\mathrm{a}_{30}$ and $\mathrm{a}_{45}$, curd firmness at $60 \mathrm{~min}$ $\left(a_{60}\right)$ was equally affected by direct and indirect effects of breed. These results on the direct effects of breed on the pattern of curd firmness in the descending part of the curve (after attainment of maximum curd firmness) 
allow us to hypothesize a direct breed effect (mainly due to genetic factors) on syneresis process of the curd.

Within cow breed, as reviewed by Bittante et al. (2012), MCP have heritability coefficients similar to those characterizing other milk traits and significant effects of milk protein genetic variants. However, it has been demonstrated that the effect of milk protein genetic variants can only partially explain the differences in coagulative traits among different breeds (Ikonen et al., 1999; Auldist et al., 2004), and this could be true for other species, such as caprine. In any case, until now, information provided by MCP have been effectively exploited to deeply investigate coagulation processes. Some authors have modeled the entire pattern of coagulation to gather further more informative curd firmness over time parameters about the technological aptitude of cattle and sheep milk (Bittante et al., 2013; Vacca et al., 2015). Some others have successfully studied models to predict MCP at population level by Fourier-transform infrared spectroscopy in cattle (Ferragina et al., 2015) and ovine species (Ferragina et al., 2017). All these information, as the comparison of different breeds on the basis of the new curd firmness over time parameters and cheesemaking ability of their milk, are still lacking in goats.

\section{CONCLUSIONS}

Information provided by this study allowed us to achieve a better representation of the effects of the different factors of coagulation. In particular, we noted an intermediate incidence of the effect of farm on the coagulative ability of milk. The factors differentiating farms were not the sole factors to influence MCP traits, but also the individual goat factors (i.e., parity and stage of lactation) were significant. Strong differences have been observed among breeds, especially between Alpine and Mediterranean goats. Even after correcting for milk yield and quality, the differences remained large especially within the Mediterranean breeds. In particular, results confirmed the very good milk quality and coagulative aptitude of autochthonous Italian goats. Further research is needed at the MCP level to investigate the entity of syneresis and to study the effects of farm and breed and nongenetic factors directly on cheese yield and milk nutrient recovery in cheese.

\section{ACKNOWLEDGMENTS}

Research was supported by the Regional Government of Sardinia (Italy; Legge Regionale 7/2007; CUP

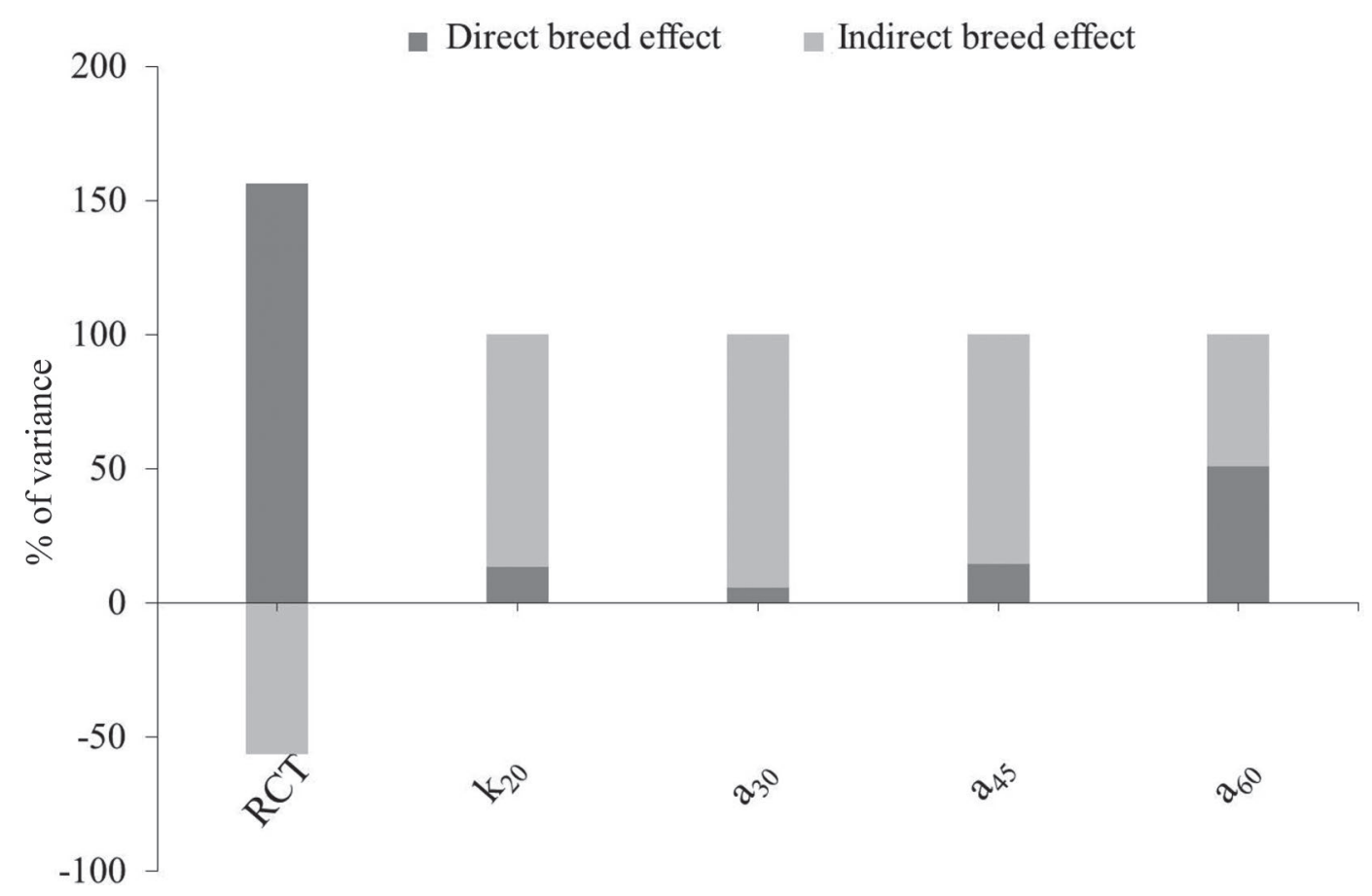

Figure 2. Proportion of total breed variance (assumed to be 100\%) of milk coagulation properties explained by direct breed effect (corrected for milk yield and quality traits) and by indirect breed effect (depending on the breed differences in milk yield and quality traits). RCT $=$ measured rennet gelation time; $\mathrm{k}_{20}=$ time interval between gelation and attainment of curd firmness of $20 \mathrm{~mm} ; \mathrm{a}_{30}, \mathrm{a}_{45}$, and $\mathrm{a}_{60}=$ curd firmness 30,45 and 60 min after rennet addition. 
J72I15000030007). The authors thank the farmers for giving access to their flocks; the Associazioni Interprovinciali/Provinciali Allevatori Associazione Regionale Allevatori (Provincial Farmers Associations) of Cagliari, Nuoro, Sassari, and Oristano (Italy) and the firms Sepi Forrmaggi (Marrubiu, Italy) and L'Armentizia Moderna (Guspini, Italy) for their support in sample collection; A.R.A. Sardegna (Associazione Regionale Allevatori; Regional Farmers Association of Sardinia, Italy) for support in chemical milk analysis.

\section{REFERENCES}

Ambrosoli, R., L. Di Stasio, and P. Mazzocco. 1988. Content of alphas1-casein and coagulation properties in goat milk. J. Dairy Sci. $71: 24-28$.

Auldist, M. J., K. A. Johnston, N. J. White, W. P. Fitzsimons, and M. J. Boland. 2004. A comparison of the composition, coagulation characteristics and cheesemaking capacity of milk from Friesian and Jersey dairy cows. J. Dairy Res. 71:51-57.

Bittante, G., B. Contiero, and A. Cecchinato. 2013. Prolonged observation and modelling of milk coagulation, curd firming, and syneresis. Int. Dairy J. 29:115-123.

Bittante, G., E. Pellattiero, F. Malchiodi, C. Cipolat-Gotet, M. Pazzola, G. M. Vacca, S. Schiavon, and A. Cecchinato. 2014. Quality traits and modeling of coagulation, curd firming, and syneresis of sheep milk of Alpine breeds fed diets supplemented with rumenprotected conjugated fatty acid. J. Dairy Sci. 97:4018-4028.

Bittante, G., M. Penasa, and A. Cecchinato. 2012. Invited review: Genetics and modeling of milk coagulation properties. J. Dairy Sci. 95:6843-6870.

Boyazoglu, J., and P. Morand-Fehr. 2001. Mediterranean dairy sheep and goat products and their quality. A critical review. Small Rumin. Res. 40:1-11.

Calvo, M. M., and E. Balcones. 2000. Some factors influencing the syneresis of bovine, ovine, and caprine milks. J. Dairy Sci. 83:17331739.

Cecchinato, A., and G. Bittante. 2016. Genetic and environmental relationships of different measures of individual cheese yield and curd nutrients recovery with coagulation properties of bovine milk. J. Dairy Sci. 99:1975-1989.

Cecchinato, A., M. Penasa, C. Cipolat-Gotet, M. De Marchi, and G. Bittante. 2012. Short communication: Factors affecting coagulation properties of Mediterranean buffalo milk. J. Dairy Sci. 95:1709-1713.

Cipolat-Gotet, C., A. Cecchinato, M. De Marchi, M. Penasa, and G. Bittante. 2012. Comparison between mechanical and near-infrared optical methods for assessing coagulation properties of bovine milk. J. Dairy Sci. 95:6806-6819.

Clark, S., and J. W. Sherbon. 2000. Alphas1-casein, milk composition and coagulation properties of goat milk. Small Rumin. Res. $38: 123-134$

Criscione, A., S. Bordonaro, V. Moltisanti, and D. Marletta. 2016. Differentiation of South Italian goat breeds in the focus of biodiversity conservation. Small Rumin. Res. 145:12-19.

DAD-IS (Domestic Animal Diversity Information System). 2014. Statistical Database of the Food and Agriculture Organization of the United Nations. Accessed Dec. 15, 2016. http://www.fao.org/dad -is/browse-by-country-and-species/en.

Devendra, C., and G. F. W. Haenlein. 2011. Animals that produce dairy foods. Goat breeds. Pages 310-324 in Encyclopedia of Dairy Sciences. 2nd ed. J. W. Fuquay, P. F. Fox, and P. L. H. McSweeney, ed. Academic Press, San Diego, CA.

Fantuz, F., F. Polidori, F. Cheli, and A. Baldi. 2001. Plasminogen activation system in goat milk and its relation with composition and coagulation properties. J. Dairy Sci. 84:1786-1790.
FAOSTAT (Food and Agriculture Organization of the United Nations Statistics Division). 2014. Statistical Database of the Food and Agriculture Organization of the United Nations. Accessed Oct. 16 2017. http://www.fao.org/faostat/en/\#data/QL.

Ferragina, A., C. Cipolat-Gotet, A. Cecchinato, M. Pazzola, M. L. Dettori, G. M. Vacca, and G. Bittante. 2017. Prediction and repeatability of milk coagulation properties and curd-firming modeling parameters of ovine milk using Fourier-transform infrared spectroscopy and Bayesian models. J. Dairy Sci. 100:3526-3538.

Ferragina, A., G. de los Campos, A. I. Vazquez, A. Cecchinato, and G. Bittante. 2015. Bayesian regression models outperform partial least squares methods for predicting milk components and technological properties using infrared spectral data. J. Dairy Sci. 98:8133-8151.

García, V., S. Rovira, K. Boutoial, and M. B. López. 2014. Improvements in goat milk quality: a review. Small Rumin. Res. 121:51-57.

Horne, D. S., and J. M. Banks. 2004. Rennet-induced coagulation of milk. Pages 47-70 in Cheese Chemistry, Physics and Microbiology. Vol. 1. Elsevier, New York, NY.

Ikonen, T., K. Ahlfors, R. Kempe, M. Ojala, and O. Ruottinen. 1999 Genetic parameters for the milk coagulation properties and prevalence of noncoagulating milk in Finnish dairy cows. J. Dairy Sci. $82: 205-214$

Ikonen, T., S. Morri, A.-M. Tyrisevä, O. Ruottinen, and M. Ojala. 2004. Genetic and phenotypic correlations between milk coagulation properties, milk production traits, somatic cell count, casein content, and pH of milk. J. Dairy Sci. 87:458-467.

Inglingstad, R. A., H. Steinshamn, B. S. Dagnachew, B. Valenti, A. Criscione, E. O. Rukke, T. G. Devold, S. B. Skeie, and G. E. Vegarud. 2014. Grazing season and forage type influence goat milk composition and rennet coagulation properties. J. Dairy Sci. 97:3800-3814.

Leitner, G., Y. Lavon, Z. Matzrafi, O. Benun, D. Bezman, and U. Merin. 2016. Somatic cell counts, chemical composition and coagulation properties of goat and sheep bulk tank milk. Int. Dairy J. 58:9-13.

Lôbo, A. M. B. O., R. N. B. Lôbo, O. Facó, V. Souza, A. A. C. Alves, A. C. Costa, and M. A. M. Albuquerque. 2017. Characterization of milk production and composition of four exotic goat breeds in Brazil. Small Rumin. Res. 153:9-16.

McMahon, D. J., and R. J. Brown. 1982. Evaluation of Formagraph for comparing rennet solutions. J. Dairy Sci. 65:1639-1642.

Mestawet, T. A., A. Girma, T. Adnoy, T. G. Devold, and G. E. Vegarud. 2013. Newly identified mutations at the CSN1S1 gene in Ethiopian goats affect casein content and coagulation properties of their milk. J. Dairy Sci. 96:4857-4869.

Moioli, B., M. D'Andrea, and F. Pilla. 2007. Candidate genes affecting sheep and goat milk quality. Small Rumin. Res. 68:179-192.

Morand-Fehr, P., J. P. Boutonnet, C. Devendra, J. P. Dubeuf, G. F W. Haenlein, P. Holst, L. Mowlem, and J. Capote. 2004. Strategy for goat farming in the 21st century. Small Rumin. Res. 51:175183.

Oliveira, R. R., L. H. A. Brasil, J. V. Delgado, J. Peguezuelos, J. M. León, D. G. P. Guedes, J. K. G. Arandas, and M. N. Ribeiro. 2016. Genetic diversity and population structure of the Spanish Murciano-Granadina goat breed according to pedigree data. Small Rumin. Res. 144:170-175.

Pazzola, M., F. Balia, M. L. Dettori, M. C. Mura, V. Carcangiu, and G. M. Vacca. 2011. Effects of different storage conditions, the farm and the stage of lactation on renneting parameters of goat milk investigated using the Formagraph method. J. Dairy Res. $78: 343-348$

Pazzola, M., M. L. Dettori, C. Cipolat-Gotet, A. Cecchinato, G. Bittante, and G. M. Vacca. 2014a. Phenotypic factors affecting coagulation properties of milk from Sarda ewes. J. Dairy Sci. 97:72477257.

Pazzola, M., M. L. Dettori, E. Pira, A. Noce, P. Paschino, and G. M. Vacca. 2014b. Effect of polymorphisms at the casein gene cluster on milk renneting properties of the Sarda goat. Small Rumin. Res. 117:124-130. 
Skeie, S. B. 2014. Review Quality aspects of goat milk for cheese production in Norway: a review. Small Rumin. Res. 122:10-17.

Stocco, G., C. Cipolat-Gotet, T. Bobbo, A. Cecchinato, and G. Bittante. 2017. Breed of cow and herd productivity affect milk composition and modeling of coagulation, curd firming and syneresis. J. Dairy Sci. 100:129-145.

Thomann, S., A. Brechenmacher, and J. Hinrichs. 2008. Strategy to evaluate cheesemaking properties of milk from different goat breeds. Small Rumin. Res. 74:172-178.

Tyrisevä, A.-M., T. Ikonen, and M. Ojala. 2003. Repeatability estimates for milk coagulation traits and non-coagulation of milk in Finnish Ayrshire cows. J. Dairy Res. 70:91-98.

Usai, M. G., S. Casu, G. Molle, M. Decandia, S. Ligios, and A. Carta. 2006. Using cluster analysis to characterize the goat farming system in Sardinia. Livest. Sci. 104:63-76.

Vacca, G. M., M. L. Dettori, V. Carcangiu, A. M. Rocchigiani, and M. Pazzola. 2010. Relationships between milk characteristics and somatic cell score in milk from primiparous browsing goats. Anim. Sci. J. 81:594-599.
Vacca, G. M., M. L. Dettori, G. Piras, F. Manca, P. Paschino, and M. Pazzola. 2014. Goat casein genotypes are associated with milk production traits in the Sarda breed. Anim. Genet. 45:723-731.

Vacca, G. M., P. Paschino, M. L. Dettori, M. Bergamaschi, C. CipolatGotet, G. Bittante, and M. Pazzola. 2016. Environmental, morphological and productive characterization of Sardinian goats and use of latent explanatory factors for population analysis. J. Anim. Sci. 94:3947-3957.

Vacca, G. M., M. Pazzola, M. L. Dettori, E. Pira, F. Malchiodi, C. Cipolat-Gotet, A. Cecchinato, and G. Bittante. 2015. Modeling of coagulation, curd firming and syneresis of milk from Sarda. J. Dairy Sci. 98:2245-2259

Zeng, S. S., and E. N. Escobar. 1995. Effect of parity and milk production on somatic cell count, standard plate count and composition of goat milk. Small Rumin. Res. 17:269-274.

Zullo, A., C. M. A. Barone, L. Chianese, P. Colatruglio, M. Occidente, and D. Matassino. 2005. Protein polymorphisms and coagulation properties of Cilentana goat milk. Small Rumin. Res. 58:223-230. 